\title{
Acute myeloid leukemia
}

INSERM

\section{Source}

INSERM. (1999). Orphanet: an online rare disease and orphan drug data base. Acute myeloid leukemia. ORPHA:519

Acute myeloid leukemia (AML) is a group of neoplasms arising from precursor cells committed to the myeloid cell-line differentiation. All of them are characterized by clonal expansion of myeloid blasts. AML manifests by fever, pallor, anemia, hemorrhages and recurrent infections. 